\title{
高磁場高勾配磁気分離による地熱水からのヒ素除去
}

\begin{tabular}{|c|c|c|c|c|}
\hline 正 員 & 岡田 & 秀彦* & 非会員 三橋 & 和成** \\
\hline 非会咠 & 工藤 & 靖男*** & 非会員 中澤 & 廣*** \\
\hline 非会員 & 藤原 & 英治**** & 正 員 小原 & 健司*5 \\
\hline & & 晶彦*** & & \\
\hline
\end{tabular}

\section{Removal of Arsenic from Geothermal Water by using High Intensity Field and High Gradient Magnetic Separation}

Hidehiko Okada*, Member, Kazunari Mitsuhashi**, Non-member, Yasuo Kudoh***, Non-member,

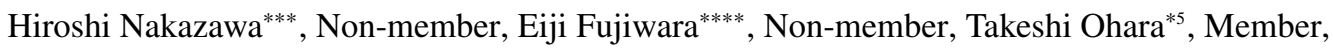
Akihiko Chiba $^{* * *}$, Non-member

We have developed a High Gradient Magnetic Separation (HGMS) system to remove arsenic from geothermal water by using a superconducting magnet. We attained the reduction of arsenic concentration less than the effluent standard of $0.1 \mathrm{mg} / \mathrm{L}$ and slightly larger than the environmental standard of $0.01 \mathrm{mg} / \mathrm{L}$ in Japan. The system consists of a pretreatment process that adds extra magnetization to arsenic by chemical reaction, and a reciprocating HGMS filter using a superconducting magnet that extracts magnetized arsenic from the geothermal water. We improved efficiency of the pretreatment process with reusing the deposition and optimiizing chemical conditions. The reciprocating HGMS filter can reduce the time for rinsing the filter. We present the experimental results of the removal system and an estimate of a practical plant to supply hot water for public use on the basis of them.

キーワード：磁気分離，高勾配磁気分離，超電導マグネット，七素，地熱水

Keywords: magnetic separation, high gradient magnetic separation, superconducting magnet, arsenic, geothermal water

\section{1. はじめに}

日本国内には現在地熱発電所は 19 箇所あり，多くが東 北，九州に設置されている( ${ }^{(1) \sim(3)}$ 。地熱発電は，地下の熱水 の貯留層から高温の蒸気を取り出し, 帯の蒸気でタービン

\footnotetext{
*(独) 物質・材料研究機構強磁場研究センター

干 305-0003 つくば市桜 3-13

Tsukuba Magnet Lab. NIMS

3-13, Sakura, Tukuba 365-0003

** 東京大学新領域創成科学研究科

干 277-8562 柏市柏の葉 5-1-5

Graduate School of Frontier Science, University of Tokyo

5-1-5, Kashiwanoha, Kashiwa 277-8562

*** 岩手大学工学部

T 020-0852 盛岡市上田 3-4-5

Faculty of Engineering, Iwate University

3-4-5, Ueda, Morioka 020-0852

**** (財) いわて産業振興センター

T 020-0852 盛岡市飯岡新田 3-35-2

3-35-2, Iiokashinden, Morioka 020-0852

*5 金沢工業大学

干 921-8501 野々市町扇が丘 7-1

Kanazawa Institute of Technology

7-1, Ohgigaoka, Nonoichi 921-8501
}

を回して発電を行うものである。地下から蒸気を取り出す 際に多くの井戶からは高温の熱水 (地熱水) も同時に取り 出されている。通常，地熱水は蒸気と分離後に還元井を通 じて地下に戻されるが, 高温, 高圧であるため光の利用方 法か以前から探られており，地熱発電所を有する各地て地 熱水の利用が試みられている。

現在, 葛根田地熱発電所 (岩手県雫石町) では 約 3000 ton $/ \mathrm{h}$ (約 $140^{\circ} \mathrm{C}, 2$ 気圧) の地熱水が井戶から得られるが，この 一部の 500 ton/h を熱交換に使い，近くの川から取水した 30 50 ton/h の河川水を温め, 得られた無害な温水を地元 の温水プール, 温泉 , 学校や温室の暖房などのために供給 している。地熱水を直接利用すれば， 1 時間に数百 $\mathrm{t}$ の温 水が利用できるのであるが，直接利用を妨げている原因は 地熱水に含まれるヒ素である (1)(4)。もし，七素を除去できれ ば供給量の大幅な増加が可能となり利用量, 利用範囲はさ らに広がると期待される。

(財) いわて産業振興センターは科学技術振興機構の岩手 県地域結集型共同研究事業で, 岩手大学, 物質 ・材料研究機 構と共同でこの地熱水の直接利用を目指して地熱水中のヒ 素を除去する方法の研究開発を行ってきた。表 1 に葛根田 
表 1 地熱水の主成分 $(\mathrm{mg} / \mathrm{L})$

Table 1. Main components in geothermal water (mg/L).

\begin{tabular}{|c|c|c|c|c|c|}
\hline $\mathrm{SiO}_{2}$ & $\mathrm{Cl}$ & $\mathrm{SO}_{4}$ & $\mathrm{Na}$ & $\mathrm{K}$ & $\mathrm{Ca}$ \\
\hline 366 & 1040 & 105 & 696 & 71.0 & 28.9 \\
\hline $\mathrm{Fe}$ & $\mathrm{Mg}$ & $\mathrm{Al}$ & $\mathrm{As}$ & $\mathrm{Br}$ & $\mathrm{F}$ \\
\hline$<0.01$ & $<0.01$ & 0.25 & 3.25 & 2.11 & 5.28 \\
\hline
\end{tabular}

地熱発電所から出る地熱水中の主な成分をまとめた。日本 におけるヒ素の排出基準は $0.1 \mathrm{mg} / \mathrm{L}$,環境基準は $0.01 \mathrm{mg} / \mathrm{L}$ である。安全に使うためにはヒ素を環境基準以下に，熱水 を使用後に河川などへ排出する場合には $0.1 \mathrm{mg} / \mathrm{L}$ 以下にす れば良いので我々は熱水中のヒ素を排出基準 $(0.1 \mathrm{mg} / \mathrm{L})$ 以 下にすることを目標とし， $3.25 \mathrm{mg} / \mathrm{L}$ のヒ素を $0.1 \mathrm{mg} / \mathrm{L}$ 以 下にする経済的な高磁場高勾配磁気分離技術を用いたヒ素 除去システムを開発した ${ }^{(11)}$ 。

磁気分離には強い磁場が必要であるが, 近年の超電導マ グネット技術の発展により, 容易に高磁場（数 T から十数 T) を広い空間に発生可能となった。この超電導マグネッ 卜と高勾配磁気分離技術を組み合わせることで今まで分離 が不可能と思われていた強磁性体以外の磁化の小さな微粒 子の効率的な磁気分離が可能となった ${ }^{(5)}$ 。

実際のプラントでは磁気分離をさらに効率的に行うため に, 分離対象物質の見かけの磁化を大きくする，例えは磁 化の大きな物質に対象物質を吸着させるような前処理プロ セスと組み合わせて使うことが多い。葛根田の地熱水中の ヒ素も磁性の弱いイオンの形で存在しているため, 乥れら の磁気分離を容易にするために，前処理として水酸化第二 鉄に吸着させ，弚の後に磁気分離を行っている。我々は二 の開発研究のため, 2000 年 12 月から葛根田地熱発電所か ら出る地熱水を使って現地で実験を行っている。

既に光の一部については報告しているので光の概要を第 2 節にまとめる。3 節以下で新しい方法による改善点と光れ に伴う，経済性の大幅な改善について述べる。

\section{2. 磁気分離によるヒ素除去の方法}

〈2 1 1 磁気分離 高勾配磁気分離技術の概要をここ では紹介する ${ }^{(5)}$ 。高勾配磁気分離は図 1 に示すように流路 中に置かれた強磁性体の針金で編んだ金網と外部に置かれ たマグネットからなる。強磁性体の針金は外部のマグネッ トからの磁場を印加すると磁化され，弚の周囲に大きな磁 場勾配を作る。光の磁場勾配による磁気力によって周囲の 磁化した粒子を磁気力て針金に引き付け，表面に捕獲する。 一般には図の樣に針金の向きは磁場勾配（磁場の変化）を 大きくするために磁場の向きと垂直になっている。

高勾配磁気分離では金網表面の堆積が多くなると捕獲能 力か落ちてくるので，ある程度溜まると堆積を取り除く必 要がある ${ }^{\left({ }^{\circ}\right.}$ 。高勾配磁気分離の原理から分かるように，外

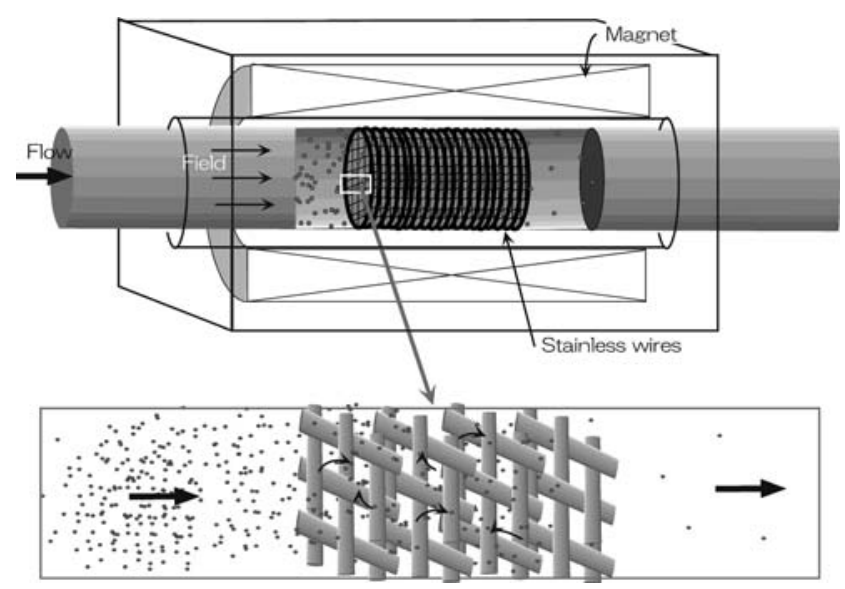

図 1 高勾配磁気分離の概略図

Fig. 1. A schematic explanation of high gradient magnetic separation.

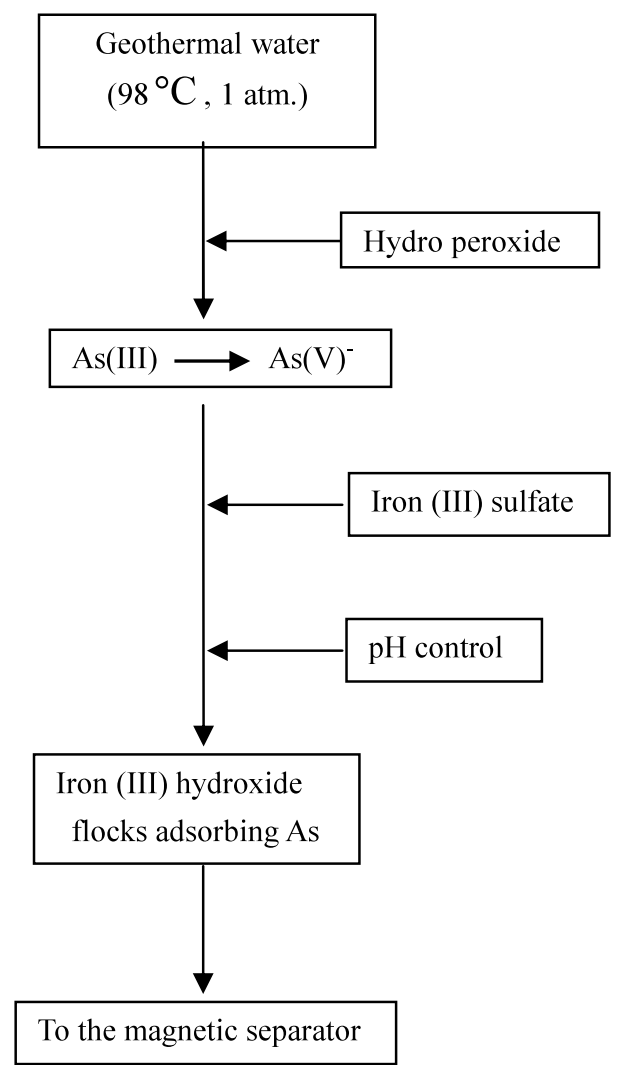

図 2 前処理プロセスの概略

Fig. 2. Diagram of pretreatment process.

部磁場をゼロにすると磁気力が消え，針金表面上の堆積を 保持することができなくなる。したがって，磁場をゼロに するか磁場から金網を出して磁気力をなくした後に，水や 空気を金網に流すことで表面の堆積を容易に取り除き捕獲 能力を回復する。実用装置では产のための洗浄システムが 磁気分離装置には備えられている。

〈2. 2〉 前 処 理 前処理方法の概要をここで述べる。 地熱水中のヒ素は $\mathrm{As}(\mathrm{III})$ 又は $\mathrm{As}(\mathrm{V})$ のイオンの形で存在 するため, 我々は水酸化鉄共沈法によって水酸化第二鉄と 
ヒ素を共沈させてから磁気分離することでヒ素を効率よく 除去する方法を開発した (7)(9)。

図 2 に我々の開発した前処理プロセスの概略を示した。 地熱水は 2 気圧 $140^{\circ} \mathrm{C}$ で供給されるが, 前処理の前に 1 気 圧に減圧して約 $100^{\circ} \mathrm{C}$ にしているこれは熱水を 1 気圧 $80^{\circ} \mathrm{C}$ 程度での利用する事を想定しているため高圧を維持 する必要がないからである。従って実験は全て減圧して 1 気圧で行っている。地熱水中のヒ素は As(III) イオンの形 でいることが多いため,より水酸化第二鉄に吸着しやすい $\mathrm{As}(\mathrm{V})$ イオンに酸化してから共沈させている。また，地熱 水に大量に含まれているシリカは水酸化第二鉄に吸着しヒ 素の水酸化第二鉄との共沈を妨害するので, 水酸化第二鉄 生成時の $\mathrm{pH}$ を 4 4.5 程度にしてしてシリカの水酸化第二 鉄への吸着を避けるようにしている。

具体的には減圧後, 必要量の 3 倍の過酸化水素水で短時 間に酸化して As(III) を As(V) にした後に硫酸第二鉄を添 加し水酸化第二鉄フロックを生成しかつシリカの影響を少 なくするために $\mathrm{pH}$ を 4 4.5 に調整する。10 分擋拌後 , 沈 殿槽に移し，凝集剂を添加して 10 分間静置してフロックを 沈殿させた後, 上澄み液を磁気分離装置に送り残った微細 な水酸化第二鉄フロックを分離する。この方法では沈殿に よって全てのフロックを分離除去する必要が無いため, 沈 殿時間は短くてすむため大きな沈殿槽の必要はない。また， 磁気分離装置は沈殿槽で分離できなかった微細なフロック のみを分離除去すればよいため, 金網に捕獲する水酸化第 二鉄の量が少なくなり頻繁に金網の洗浄を行う必要が無い。

〈2 3〉 磁気分離実験装置図 3 に葛根田での磁気分 離実験装置の写真を示す。奥に見えるタンクが反応槽 $(\mathrm{Re}-$ actor) および沈殿槽 (Settling Tank) である。手前に見える のが超電導マグネット (JASTEC 社製，10 T , 室温ボア径 $10 \mathrm{~cm})$ である。超電導マグネットの中央部を貫通している のが強磁性体の金網を詰めた磁気分離部である。磁気分離 部は reciplocating magnetic separation fileter と呼ばれる構 造をしており，この筒は二重構造になっており，内部の筒 が上下に動き捕獲と金網の洗浄を交互に行う ${ }^{(6)}$ 。

実験装置の概略を図 4 に示す。発電所から送られてきた 熱水は反応槽 (Reactor) に入れる際に 1 気圧に減圧される。 反応槽には最大 $100 \mathrm{~L}$ の熱水を溜められるが安全のため通 常は $80 \mathrm{~L}$ で実験を行っている。反応槽内で過酸化水素水を 添加しヒ素の酸化を行ってから, 硫酸鉄を添加して $\mathrm{pH}$ 調 整を行い水酸化第二鉄フロックへヒ素を吸着を行った後, 沈殿槽 (Settling Tank) に送りフロックを沈殿させる。沈 殿後上澄み液を磁気分離装置にポンプで送り熱水中に残っ た水酸化第二鉄の微粒子を除去する。分析用の試料は磁気 分離前後で採取する。磁気分離部は，マグネットと金網の 概略のみを描いている。

磁気分離部の内部構造,つまり reciplocating magnetic separation filter の内部構造の概念図を図 5 に示す ${ }^{(6)}$ 。内側の 直径 $50 \mathrm{~mm}$ のステンレスの管の内部は上下に二つに分かれ ており全く同じ構造をしている。光れ光れ直径 $100 \mu \mathrm{m}$ の

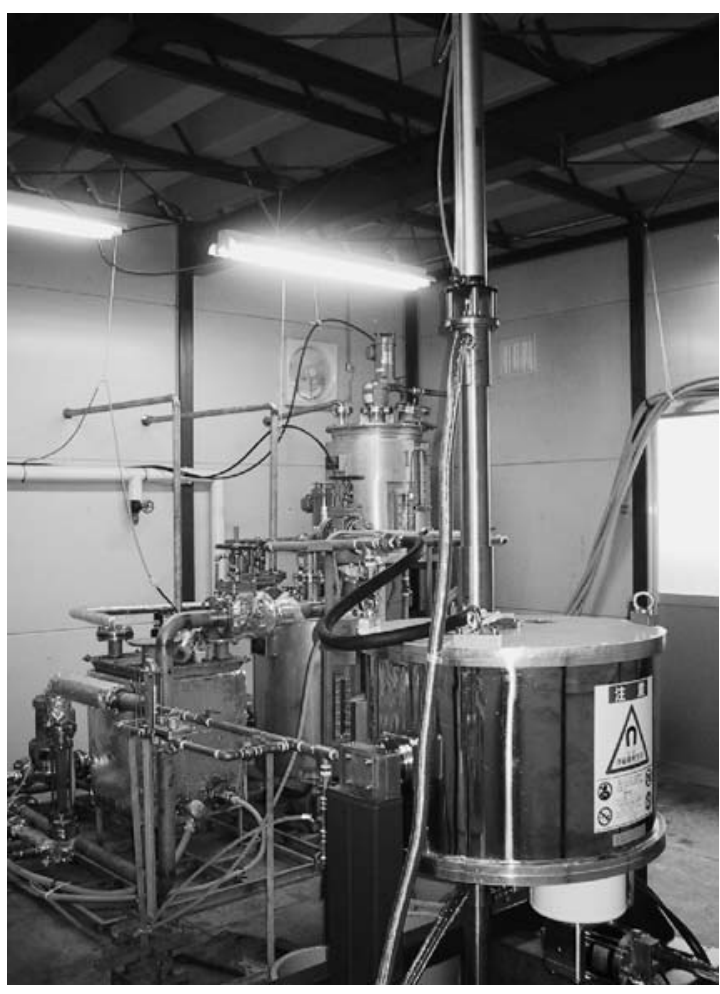

図 3 磁気分離実験装置の外観

Fig. 3. A photogragh of the experimental setup of magnetic separation.

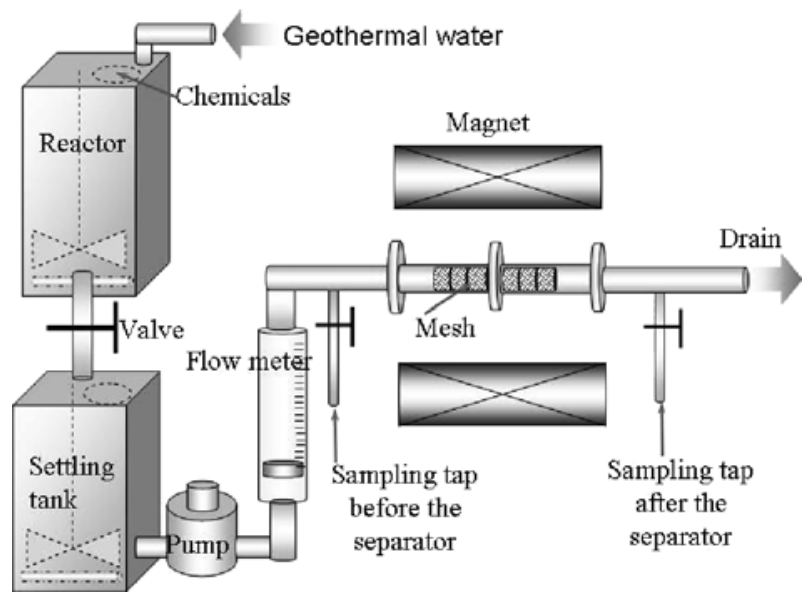

図 4 磁気分離実験装置の概略図

Fig. 4. A Diagram of the experimental setup of magnetic separation.

ステンレススチール (SUS430) の針線で編んだ金網が同 量 (1000 枚) ずつ $60 \mathrm{~cm}$ の長さに一樣に詰められている。 分離の際にはどちらか一方がマグネットの内部に入るよう に移動し磁気分離を行う。図 5 の樣に前処理後の熱水は下 の口から入り, 金網の部分で磁気力により水酸化第二鉄フ ロックは金網に捕らえられる。フロックを除かれた熱水は 上の口から出て行く。金網にフロックが溜まり捕獲能力が 落ちてきた場合は, 金網を外の磁場の弱いところに移動さ せる。移動し終わると上の口から水又は空気を送り込んで 


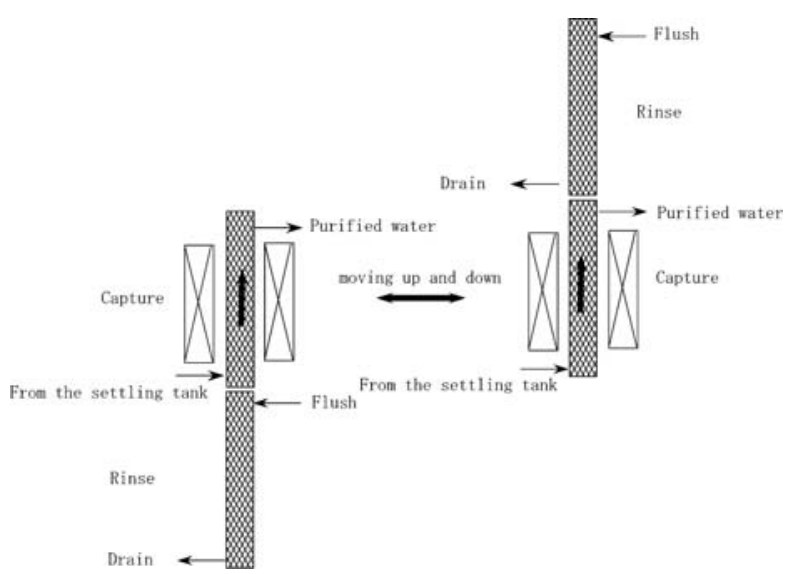

図 5 レシプロ型磁気分離装置の概略図

Fig. 5. Schematic explanation of the reciplocating magnetic separation filter.

堆積を洗い流す。これと同時に，繋がっているもう一方の 金網を設置した部分がマグネット内部に移動しフロックの 捕獲を行う。产のため移動時間を除いてほぼ連続的に捕獲 が行える。葛根田に設置したレシプロ型磁気分離装置では 内部の筒の上下の移動に空気圧を用いている。この方法で は, 移動時間の数秒間のみ捕獲が行われないだけで, 事実 上連続的に水酸化第二鉄の捕獲が行われるため, 磁気分離 の効率は大幅に向上し熱水の処理速度も大幅に向上するこ とになった。

\section{3. 前処理方法の改善}

以前の実験の結果を使ってヒ素除去プラントの運用コス 卜を見積もったところ ${ }^{(9)(10)}, 1$ トン当たりの地熱水からヒ素 を除去するには 130 円の費用か溎かり，光の約 70\%が前処 理で使用する薬品代であると試算された。关のため，前処 理の薬品の使用量の低減を目指して，前処理の実験を行っ た結果，一度使用した沈殿を再び使用すると薬品の添加量 を少なくしても十分にヒ素を吸着できることが分かった。 この方法の概念図を図 6 に示す。太い破線の部分が新たに 付け加えたプロセスである。つまり沈殿槽に残ったヒ素を 吸着した水酸化第二鉄の沈殿物を廃棄せずに, 酸化後の地 熱水に硫酸鉄と一緒に混ぜて摚拌， $\mathrm{pH}$ 調整を行い新たな 水酸化第二鉄フロックを生成しヒ素を吸着させる。従って， 手順としては, 反応槽で水酸化第二鉄の生成は行わず酸化 か終わった熱水は沈殿槽に送り前回の沈殿と混ぜた後，硫 酸鉄を添加して水酸化第二鉄生成, 擋拌後水酸化第二鉄フ ロックを沈殿させる。沈殿した後で，上澄み液を磁気分離 する。この方法では水酸化第二鉄フロックが䋹り返し使用 されるので水酸化第二鉄の吸着能力を十分に生かせるため, 添加する薬品量が減らせると考えられる。

\section{4. 磁気分離実験}

前節で述べた前処理方法と磁気分離の条件の最適化を目 的とした実験を葛根田の地熱水で行った。この節では光の

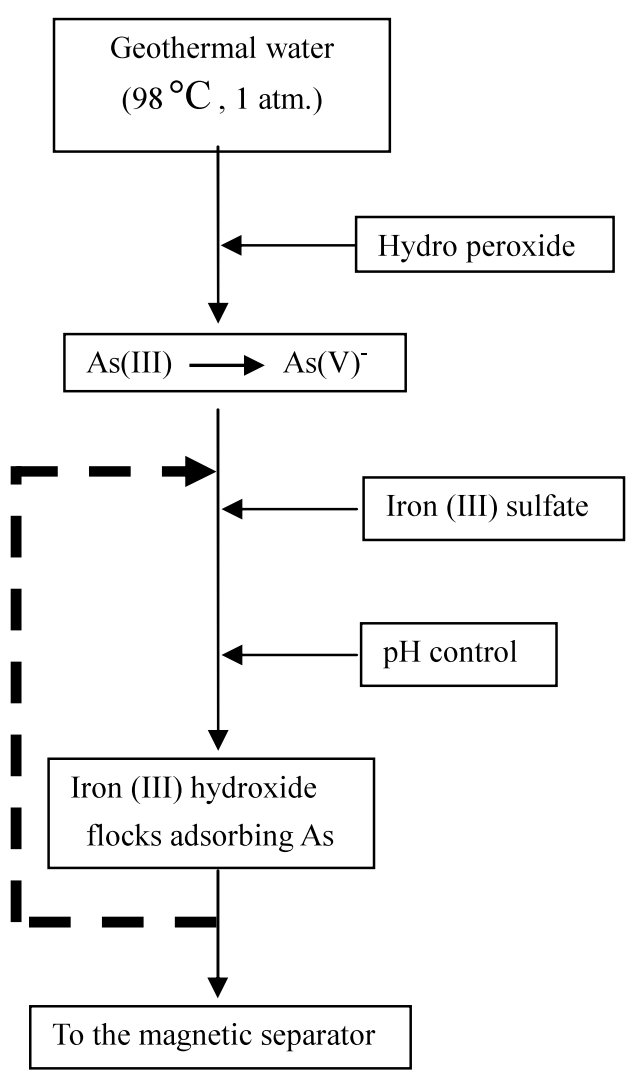

図 6 改善された前処理方法 (太い破線が追加プロセス) Fig. 6. Diagram of the modified pretreatment process (The fat broken line shows the additional process).

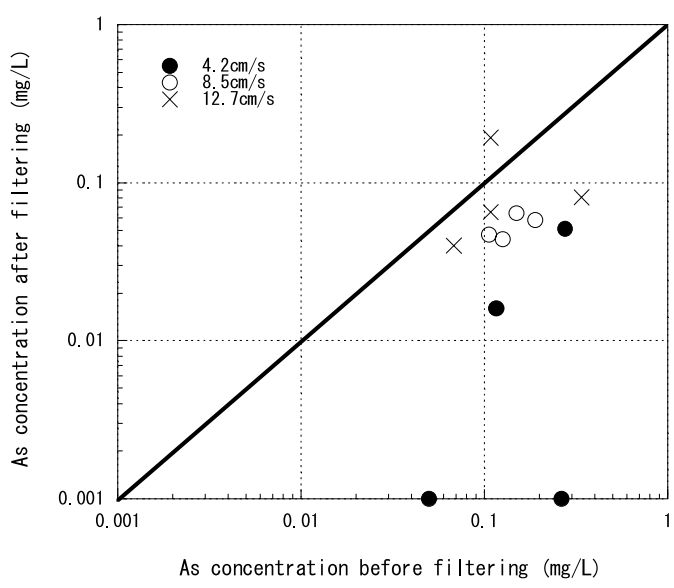

图 7 磁気分離前後のヒ素濃度 (斜めの実線より 下では磁気分離が有効である)

Fig. 7. As concentrations of each experiment before and after the magnetic separation (The magnetic separarion is effective below the solid line).

結果について述べる。

図 7 は最適な磁気分離の処理速度 (磁気分離装置を熱水 が通過する際の流速）を調べるための実験の結果で, 速度 を変えたときの分離前後のヒ素濃度を示した。磁場強度は 2Tである。この実験の前処理では沈殿は繰り返し使わず硫 酸鉄を $\mathrm{Fe}(\mathrm{III})$ 濃度で $80 \mathrm{mg} / \mathrm{L}$ 添加している。横軸が磁気 


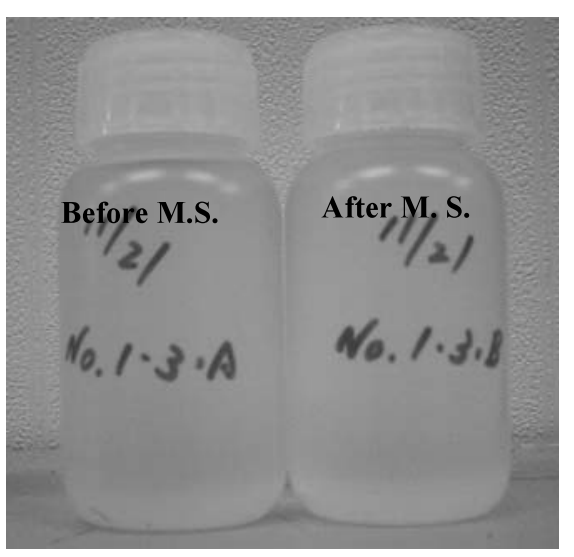

図 8 磁気分離前後の試料 (分離前の黄色が完全に 消えて透明になっている)

Fig. 8. Samples before and after the magnetic separation (The sample after M. S. is clearer).

分離前の沈殿後の上澄み液中の七素濃度，縦軸が磁気分離 後の七素濃度である。実線上では, 磁気分離前後でヒ素濃 度が変わらない，つまりこの実線より上側では磁気分離の 効果が無いことになる。3 種類の流速で実験を示している が, 流速が遅いほど点の位置が実線から離机磁気分離が有 効であることが分かる。ヒ素除去システムの実用化には経 済性が大きな課題となる。磁気分離装置には安定して高速 でヒ素を排出基準 $(0.1 \mathrm{mg} / \mathrm{L})$ 以下まで除去することが要 求される。流速 $8.5 \mathrm{~cm} / \mathrm{s}$ は, 分離前には $0.1 \mathrm{mg} / \mathrm{L}$ の素濃 度を分離後には常に $0.1 \mathrm{mg} / \mathrm{L}$ 以下にできているため, 我々 の目的である，排出基準を達成しかつ高速で分離ができる 条件を満たしていると考え，この実験から $8.5 \mathrm{~cm} / \mathrm{s}$ 程度が 適当と考えた。一方, 環境基準以下の $0.001 \mathrm{mg} / \mathrm{L}$ までヒ素 が咸っているデータがあるが，再現性に乏しいためさらに 実験を行っている。

图 8 は分離前後の試料の写真である。左か磁気分離前の 試料で, 沈殿て除去できなかった水酸化第二鉄の微粒子が 浮遊し濁っている。右か磁気分離後の試料て磁気分離によ り水酸化第二鉄微粒子か除去されて透明になっていること が分かる。

图 9 は図 6 に示した硫酸第二鉄を毎回添加すると共に， 乥れ以前の水酸化第二鉄沈殿も添加することを繰り返す(つ まり回を重ねるごとに鉄濃度は増えている）前処理方法を 10 回続けて行った結果である。一回に添加している硫酸第 二鉄の濃度は $\mathrm{Fe}(\mathrm{III})$ で $40 \mathrm{mg} / \mathrm{L}$ である。ヒ素の濃度は各 回の磁気分離前後で測定したものである。回を追うごとに 磁気分離前のヒ素濃度が低下し,さらに磁気分離によって 低下していることが分かる。また，前処理のみではヒ素濃 度が大きく変動しているが, 分離後にはばらつきが小さく なっている。また , 3 回目以降の磁気分離後には常に排出 基準以下になっており沈殿物を繰り返し使う方法が有効で あることがわかった。10回目になると磁気分離前のヒ素濃 度も $0.1 \mathrm{mg} / \mathrm{L}$ 以下になっている。これは前処理の薬品量の

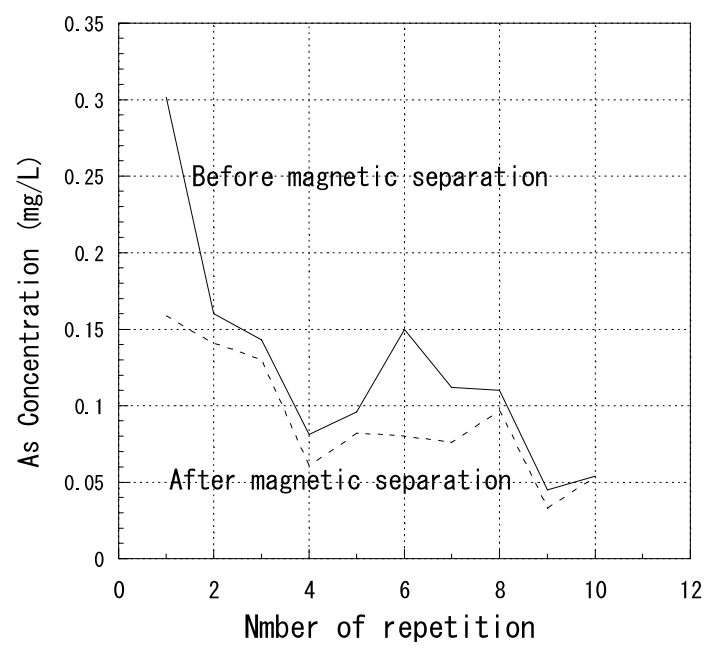

図 9 沈殿物を繰り返し使った場合の磁気分離前後の 七素濃度の変化 (実線は磁気分離前, 点線は 磁気分離後である)

Fig. 9. Function of As concentration on number of repetition of deposition (The solid line shows As concentration before the magnetic separation and the dotted line shows As concentration after the magnetic separation).

表 2 処理後の地熱水中の主な成分の濃度

Table 2. Concentration of main constituents in processed geothermal water $(\mathrm{mg} / \mathrm{L})$.

\begin{tabular}{|c|c|c|c|c|c|}
\hline $\mathrm{SiO}_{2}$ & $\mathrm{Cl}$ & $\mathrm{SO}_{4}$ & $\mathrm{Na}$ & $\mathrm{K}$ & $\mathrm{Ca}$ \\
\hline 332 & 1050 & 105 & 794 & 72.0 & 30.7 \\
\hline $\mathrm{Fe}$ & $\mathrm{Mg}$ & $\mathrm{Al}$ & $\mathrm{As}$ & $\mathrm{Br}$ & $\mathrm{F}$ \\
\hline 6.4 & 0.24 & 0.49 & 0.020 & 1.55 & 4.37 \\
\hline
\end{tabular}

更なる低減が可能な事を示唆している。

この繰り返し沈殿物を使うと水酸化第二鉄フロックの大 きさが大きく緻密になって沈殿の密度が上がり, 沈殿の見 かけの容積があまり変化しないこともわかった。

表 2 にヒ素除去後の地熱水中の主要成分の濃度の一例を 示す。この試料ではヒ素が $0.02 \mathrm{mg} / \mathrm{L}$ まで咸少している。 鉄を添加しているため鉄の濃度が上昇している。また , $\mathrm{pH}$ も地熱水は 8.5 であったが水酸化第二鉄生成時の $\mathrm{pH}$ 調整 により処理後は 3.9 になっている。これまでの研究開発の 結果から，実際の地熱水中のヒ素を常に排出基準よりはる かに少ない $0.03 \sim 0.02 \mathrm{mg} / \mathrm{L}$ 程度にまで除去できる磁気分 離を用いた除去技術を確立したといえる。

\section{5. 磁気分離装置の大型化}

前節までの実験は実験条件を変えることが比較的容易な ように比較的小さな規模での実験装置で行ったため, 磁気 分離装置の金網部の断面積の直径は $50 \mathrm{~mm}$ であった。実際 のヒ素除去プラントで大量処理を行う場合, 断面積の大き な磁気分離装置を使えば少数の超電導マグネットで大量の 
熱水を処理できるため, 非常に経済的である。

磁気分離の捕獲能力は他の条件が同じならば流速には依 存するが, 処理量つまり断面積には依存しないと言われて いる。我々はすでに磁気分離部の内部構造（金網の枚数や 形状) の依存性については調べたが(8)，断面積の依存性に ついては実験装置の制約から調へていなかった。断面依存 性について調べるため今までの 16 倍の断面積を持つ直径 $200 \mathrm{~mm}$ の実験装置を作り光の分離性能を調べ今までの実 験と比較した。内部の金網は $50 \mathrm{~mm}$ の場合と同じく直径 $100 \mu \mathrm{m}$ の針金を編んだものを 1000 枚使った。一回の実験 には大量な ( $0.4 \mathrm{t} / \mathrm{min}$ 程度必要) 水が必要であるが，葛根 田の設備では大量の熱水を前処理できないため, 室温の水 道水中で水酸化第二鉄を生成し弚の水酸化第二鉄の分離性 能を葛根田での実験と比較した。但し，過酸化水素水の添 加，水酸化第二鉄生成の $\mathrm{pH}$ などの他の条件は全て同じに した。前処理でヒ素は水酸化第二鉄フロックに吸着し, 乥 の水酸化第二鉄フロックの磁化によって磁気分離をしてい る。つまり，七素除去の性能は水酸化第二鉄フロックの除 去能力によって決まる。したがって，磁気分離後のヒ素濃 度が $0.1 \mathrm{mg} / \mathrm{L}$ 以下になった地熱水のサンプルの鉄濃度と， 大型実験装置での鉄濃度を比較検討すれば，大型実験装置 のヒ素除去の性能評価ができる。

図 10 に光の結果を示す。 $50 \mathrm{~mm}$ と書かれているものは 以前の地熱水を使った直径 $50 \mathrm{~mm}$ の金網の実験で分離後の 七素濃度が $0.1 \mathrm{mg} / \mathrm{L}$ 以下になったサンプルの磁気分離前後 の鉄濃度である。図 10 を見ると，断面積を 16 倍にした大 型装置での水酸化第二鉄の分離性能は葛根田で使用した直 径 $50 \mathrm{~mm}$ の結果よりも良くなっている。これは使用した金

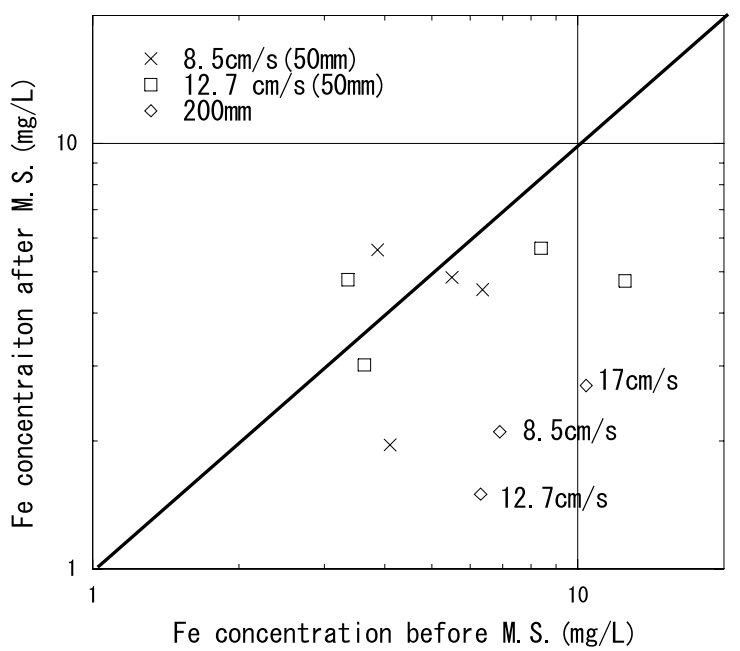

図 $1050 \mathrm{~mm}$ と $200 \mathrm{~mm}$ の磁気分離装置の効率の比較 (〉は $200 \mathrm{~mm}$ の時の流速 $8.5,12.7,17 \mathrm{~cm} / \mathrm{s}$ の時の 鉄濃度である。実線よりも下側では磁気分離が 有効であると言える)

Fig. 10. Compariton of efficiency with magnetic separator of $50 \mathrm{~mm}$ and $200 \mathrm{~mm}(\diamond$ shows experimental results at fluid velocity of $8.5,12.7$ and $17 \mathrm{~cm} / \mathrm{s}$. The magnetic separation is effective under the diagonal solid line).
網が新しいためと思われる。大型実験装置での実験では磁 気分離前の水酸化第二鉄濃度は以前の実験と比べると全般 的に少なくなっており，光れにつれて分離後の濃度も少な くなっている。また, $50 \mathrm{~mm}$ の場合 , 実線よりも上側に点 があるが，これは濃度の摇らぎの影響と思われる。

以上の結果から磁気分離装置の断面積を大きくしても性 能は落ちずあまり变わらないと考えられ，葛根田での $50 \mathrm{~mm}$ の実験の結果か断面積を大きくしても有効であり，将来の 実証プラントなどの大型装置の設計などにも有効であるこ とが分かった。

\section{6. ヒ素除去プラントの検討}

既に文献(10)において，初期の実験結果を使ってヒ素除 去プラントの検討を行った。今回は, 前処理の薬品量 , 特 に硫酸第二鉄の添加量が $150 \mathrm{mg} / \mathrm{L}$ から $40 \mathrm{mg} / \mathrm{L}$ へ大幅に 低減した事, 磁気分離装置内を流れる流速が $3.3 \mathrm{~cm} / \mathrm{s}$ から $8.5 \mathrm{~cm} / \mathrm{s}$ と 2 倍以上になった事, 磁気分離装置の洗浄時間 が 1 時間に 10 分必要であったのが, レシプロ型磁気分離装 置の使用により洗浄時間が事実上無くなった事などにより， 大幅に設備費，運営費が削減されることが分かった。特に 磁気分離装置が 8 台から 2 台に削減可能となったため建設 費が大幅に減少した。

先に述べたように現在葛根田で温水を零石町に供給して いる熱交換プラントは一時間に $30 \mathrm{t}$ から $50 \mathrm{t}$ の温水を造っ ている。今回の新しい実験データを使い既存の施設と同等 の能力を有する, 温水製造能力 $40 \mathrm{t} / \mathrm{h}$ のヒ素の排出基準を 満たす温水を供給可能な磁気分離を使った温水製造プラン トの概念設計を行った。

表 3 に新しい実験結果から得られたこの条件を満足する ための磁気分離装置の概要をまとめる。流速及び磁場強度 は実験から得られた值である。磁気分離装置に使う超電導 マグネットは冷凍機冷却式とし，断面積は製造に問題が無 い樣に市販の超電導マグネットの最大のものと同じにした。 これらの值が決まると一台あたりの処理量が決まるため， 超電導マグネットの台数が決まる。この条件では磁気分離 装置 2 台で約 $40 \mathrm{t} / \mathrm{h}$ の処理が可能となる。また, 前処理に 必用な薬品は $\mathrm{Fe}(\mathrm{III}) 40 \mathrm{mg} / \mathrm{L}$ 相当の硫酸鉄を使って処理す るとし必要な薬品量を求め概念設計を行った。光の結果 4 器の容量 $25 \mathrm{~m}^{3}$ の沈殿槽を兼ねる化学反応槽, 5 器の薬品貯 蔵タンク及び配管，ポンプ，擋拌装置等が必要となる。ま た，約半年の建設期間を必要とする。表 4 に建設費と運営

表 3 磁気分離装置の主な仕樣

Table 3. Specification of the magnetic separator.

\begin{tabular}{|l|l|}
\hline Fluid velocity & $8.5 \mathrm{~cm} / \mathrm{s}$ \\
\hline Field strength & $2 \mathrm{~T}$ \\
\hline Diameter of the magnetic separator & $30 \mathrm{~cm}$ \\
\hline Number of superconducting magnet & 2 \\
\hline
\end{tabular}


表 4 建設費と運営費

Table 4. Building and operating costs.

\begin{tabular}{|l|l|}
\hline Building costs & 357 million yen \\
\hline Operating expense per ton & 62 yen/ton \\
\hline Operating expense per year & 27 million yen \\
\hline
\end{tabular}

費の概要をまとめた。

表 4 の建設費は温水製造プラントのみの建設費であり， 温水を送るパイプライン等の建設費は含まれていない。発 電所からプラントまで熱水を送るパイプラインや地元への 供給用のパイプライン及びとの管理システムは既存の物を 使うこととした。また，運営費には，廃棄物の処理費用，維 持管理費，管理のための人件費は含まれていない。費用の 内訳を見ると建設費 3 億 5700 万円の内磁気分離装置 2 台 の值段は約 4000 万円で，全建設費の $10 \%$ 程度である。ま た，運営費の 70\%か薬品費である。同じく超電導マグネッ

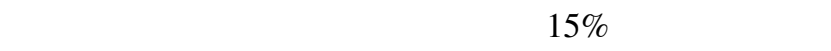
らの設備は $25 \mathrm{~m} \times 25 \mathrm{~m}$ の敷地にすべて収まる広さである。

\section{7. まとめと今後の課題}

1999 年からの研究の結果 ${ }^{(9)}$, 地熱水中のヒ素を磁気分離 によって排出基準以下にする技術を開発した。また光の技 術を使ったプラントの概念設計を行った。光の結果排出基 準以下にヒ素を除いた熱水を約 $40 \mathrm{t} / \mathrm{h}$ で供給するには約 62 円/t の費用がかかことが分かった。灯油を使ったボイラー で温水を造る場合の費用は約 400 円/ $\mathrm{t}$ と言われているので， 製造のみではあるが十分に経济的な技術を開発したといえ る。また ,この費用のほとんどが薬品費であることから，前 処理の改善でさらに安くすることは可能である。この概念 設計にに含まれていない管理費なども運転の自動化により 減らすことは可能である。

現在の熱交換施設は $100 \mathrm{~m} \times 100 \mathrm{~m}$ 以上の設置面積を必 要とするが, 今回の設計で設置面積を大幅に縮小できるこ とがわかった。これは, 我が国の地熱発電所の多くが国立 公園内にあることを考えると自然環境の保護から重要なこ とである。

ヒ素濃度を $0.02 \mathrm{mg} / \mathrm{L}$ と環境基準 $(0.01 \mathrm{mg} / \mathrm{L})$ に近いと ころまで除去することに成功しているため, さらに研究を 進めれは環境基準を達成する技術も開発できると思われる。 飲料水中のヒ素は世界中で問題となっているので(11)，さら に研究を続け飲料水への応用も視野に入れて研究を続けた いと考えている。

本研究は, 科学技術振興機構 岩手県地域結集型共同研究 事業 (生活・地域への磁気活用技術の展開) の一環として 行われたものである。

この研究を実施するに当たり，岩手県の関係部所及び地 熱エンジニアリング (株) の柳谷氏には葛根田熱水造成施 設の利用などいろいろと便宜を図っていただいたばかりで なく，この研究に大きなご支援，ご協力をいただいたこと
に感謝いたします。

(平成 16 年 8 月 26 日受付, 平成 17 年 1 月 24 日再受付)

文献

( 1 ) J. Umeno and T. Iwanaga: Proc. of the 20th New Zealand Geothermal Workshop, pp.209-213 (1988)

（2）山田茂登 : 配管・装置・プラント技術, Vol.39, p.19 (1999)

(3) 新妻弘明: 電学誌, Vol.117, p.751 (1997)

（4）梅野丈二・岩永達人：地熱エネルギー, Vol.24, p.40 (1999)

（5）小原健司・渡辺恒雄・西嶋茂宏・岡田秀彦・佐保典英：応用物理, Vol.71, p.57 (2002)

(6) L.G. Yan, S.S. Song, C.L. Yi, Z.X. Ye, H.L. Nan, G.B. Tu, X.S. Li, X.Y. Li, and J.X. Zheng: "Laboratory Test of an Industrial Superconducting Magnetic Separator for Kaolin Clay Purification", IEEE Trans. Mag., Vol.30, pp.2499-2502 (1994)

（7）中澤 廣・佐藤敏人·長谷部茂: 資源と素材, Vol.105, p.239 (1989)

( 8 ) H. Okada, T. Tada, A. Chiba, K. Mitsuhashi, T. Ohara, and H. Wada: "High gradient magnetic separation for weakly magnetized fine particles", IEEE Trans. Appl. Supercond., Vol.12, pp.967-970 (2002)

( 9 ) A. Chiba, H. Okada, T. Tada, H. Kudoh, H. Nakazawa, K. Mitsuhashi, T. Ohara, and H. Wada: "Removal of arsenic from geothermal water by high gradient magnetic separation”, IEEE Trans. Appl. Supercond., Vol.12, pp.952-954 (2002)

(10) H. Okada, T. Tada, A. Chiba, H. Nakazawa, K. Mitsuhashi, and T. Ohara: "Decontaminataion of Geothermal Water-Removal of Arsenic_-", J. Cryo. Soc. Jpn, Vol.37, No.7, pp.331-337 (2002) (in Japanese)

岡田秀彦・多田朋弘・葉晶彦・中澤 廣 - 三橋和成 - 小原健司 : 「地熱水の無害化一七素の除去一」, 低温工学誌, 37, No.7, pp.331-337 (2002)

(11) 平野英男 : 砒素をめぐる環境問題, 第 7 章, 日本地質学会環境地質研 究委員会編, 東海大学出版会, 東京 (1998)

(12) H. Okada, Y. Kudoh, H. Nakazawa, A. Chiba, K. Mitsuhashi, T. Ohara, and H. Wada: "Removal System Of Arsenic From Geothermal Water by High Gradient Magnetic Separation-HGMS Reciprocal Filter-", IEEE Trans. Appl. Supercond., Vol.14, No.2, pp.1576-1579 (2004)

岡田秀彦 (正員) 1951 年 8 月 17 日生。1982 年 3 月東京

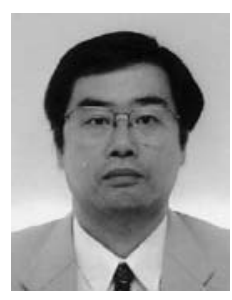
工業大学理工学研究科物理学専攻博士課程修了。 1992 年(株)東芝研究開発センター勤務。1999 年 (財)いわて産業振興センター勤務。2004 年(独) 物質・材料研究機構勤務。主に超電導応用研究に 従事。理博。

三橋 和 成 (非会員) 1974 年 9 月 24 日生。 2004 年 3 月筑

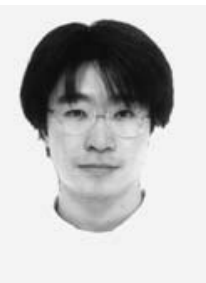
波大学大学院数理物質科学研究科物質創成先端科 学専攻博士課程中退。2004 年 4 月東京大学大学 院数新領域創成科学研究科物質系助手。修士 (理 学・工学)。主に磁気分離用磁性吸着材の開発の 研究に従事。

工 藤 靖 夫 (非会員) 1943 年 3 月 11 日生。1962 年 3 月盛

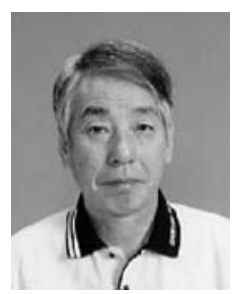
岡第一高等学校卒業。1962 年 4 月岩手大学事務 職員。1965 年 10 月岩手大学工学部技術専門官。 2003 年 3 月退職。 
中 澤 廣 (非会員) 1952 年 5 月 7 日生。1 1978 年 3 月東 北大学大学院工学研究科資源工学専攻前期課程修 了。1978 年 4 月岩手大学工学部助手。1983 年 9 月〜1985 年 7 月米国ミネソタ大学鉱物資源研究 センター客員研究員。1990 年 1 月岩手大学工学 部助教授。1995 年 4 月岩手大学工学部教授（建 設環境工学科)。工博。

藤 原 英 治 (非会員) 1979 年 8 月 7 日生。2004 年 3 月岩

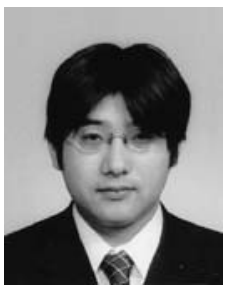

小 原 健 司 (正員) 1948 年 11 月 28 日生。1974 年 3 月千葉 大学大学院工学研究科修士課程修了。同年 4 月通 産省工技院電子技術総合研究所入所。1985 年〜 1986 年米国マサチューセッツ工科大学フランシ ス・ビター国立磁石研究所客員研究員。2001 年 4 月(独)物質材料研究機構転任。2004 年 4 月金沢 工業大学工学部電気電子工学科教授。物質材料研 究機構終身名誉研究員。応用物理学会, 日本応用 磁気学会, 日本鉄鋼協会, 低温工学協会, つくばアカデミー会員。強 磁場応用研究に従事。工博。

千 葉 晶 彦 (非会員) 1957 年 5 月生, 1985 年 3 月岩手大学 大学院修士課程金属工学専攻修了, 1985 年 87 年(株)日立製作所日立研究所勤務 1987 年 7 月岩 手大学工学部金属工学科助手, 1991 年 4 月同助 教授，2000 年 4 月同福祉システム工学科助教授， 2002 年同教授 2000 年より(独)物質・材料研究機 構生体材料研究センター客員研究官, 主に生体材 料の研究に従事。工博。 